\title{
The Benefits and Problems of International Trade in Context of Global Crisis*
}

\author{
Ercan Ekmekçioğlu \\ Kyrgyz Turkish Manas University, Bishkek, Kyrgyzstan
}

\begin{abstract}
The undertaking of this study is to analyze the different benefits and problems of international trade and how this industry is affected by the global crisis. The advancement of information technology in terms of communication has changed the business environment and trade industry. Numerous benefits can be obtained by participating in the international trade industry and the WTO extends their policies and implementation of the agreement to fairly accommodate all participating countries. This article intends to investigate the three major factors affecting the trend in the marketing and trade industry over the years due to the changes in business environment. These changes are mainly caused by the development of information technology, globalization and the power of concentration among countries. The problem, however, arises when the top players in the trade industry control these policies and misunderstandings from critics give in to the argument of fairness in trade transactions. This article also discusses the prediction of global exchange rate in the following years and the cause of the global financial crisis. The different losses and bailouts for US and European countries is analyzed and its effect on the international trade industry and the author suggests possible solutions for the betterment of the trade industry in general.
\end{abstract}

Keywords: international trade, global crisis, developing countries

\section{Introduction}

The exchange of goods, services, capital between countries and regions is referred to as International Trade and it has given rise to the global economy. There are different forms of trade and the advancement in technology has also changed the economic trend among various industries. In such a way that international trade, most especially in terms of supply and demand is directly related to the events happening all over the world (Heakal, 2003).

International trade has sparked a lot of debate in recent times as the world seems to be becoming virtually smaller every day, the stringent and largely formal procedures that formed the basis of trade in the past have come tumbling down especially in this age of information technology, where platforms to communicate with almost any one has turned the world into a global village. For effective trade, however, there are some factors that come

\footnotetext{
* This paper was submitted in International Conference on Eurasian Economies 2011. The conference held in Bishkek, Kyrgyzstan at the heart of Central Asia, http://www.eecon.info/.

Ercan Ekmekçioğlu, Lecturer-Doctor, Department of Economy, Faculty of Economics and Management, Kyrgyz Turkish Manas University.

Correspondence concerning this article should be addressed to Ercan Ekmekcioglu, Manas Street No.56, Bishkek 720044, Kyrgyzstan. E-mail: ercan.ekmekcioglu@manas.edu.kg.
} 
into play, which include: the level of technological advancement, liberalization of trade and capital markets, accessibility to information, capital internationalization and the international labor division; these factors set the ground for trade, if all these factors were standardized the world over, then benefits from international trade would be fair across the board but this is not the reality of our world and this factors in turn determine the extent to which a country benefits (Worldbank.org, 2011).

The major benefits felt from international trade are promotion of information exchange which has led to better cultural understanding of different people, it can be attributed to raising the living standards of some people, it has promoted democracy, raised purchasing power of some nations; there is a general feeling of a more united world and countries no longer operate in isolation (Worldbank.org, 2011).

The most alarming trend of international trade however it is increasing the gap between the rich and the poor , the terms of trade are not fair and developed nations seem to be getting all the benefits while the developing nations get a raw deal; it can be termed as modern day imperialism. Today, countries are more affected by the trends of other countries, e.g., if there is a recession, it is likely to be felt across the board, some corporations have taken advantage of relocate businesses to countries with cheap labor and weak environmental laws increasing environmental degradation (Worldbank.org, 2011).

This paper intends to analyze the different benefits and problems of international trade in the aspects of information technology modernity and the global crisis that occurs nowadays.

\section{Information Technology}

Three major factors have affected the trend in the marketing and trade industry over the years due to the changes in business environment. These changes are mainly caused by the development of information technology, globalization and power concentration (Albercht \& Sack, 2000, p. 6). The advancement in information technology has paved way to a faster and efficient world for international trade. Investors can communicate easily with just a click of a button and an investor can now process their business transactions online. They may also monitor the stock exchange, foreign exchanges, import and export through their mobile phones or through different accessible financial websites.

Due to the effect of information technology in the nature of international trade, many companies are interested in outsourcing their businesses as well. Larson (1996) states that:

Today, technological innovation is required to satisfy customers' demands for lower prices, faster delivery, and higher quality products and services. These demands, coupled with a globally competitive environment, place a great deal of pressure on the profit margins of manufacturers, service providers, and export trading companies alike.

To survive in this environment, businesses must effectively use technology to ensure that they can tap into the right information and act on it quickly.

It has been established that information technology is essential in doing business transactions internationally, most especially in trading goods and services. Therefore, countries participating in international trade also develop their system and technology to cope up with the environment. An example are financial websites such as Bloomberg that provide the most updated news, data, trade information and it can be viewed by people all over the world. According to the website of Bloomberg (2011), "bringing transparency to capital markets through access to information could increase capital flows, produce economic growth and jobs, and significantly reduce 
the cost of doing business". With this, investors all over the world participate in international trade online and can easily access to vital information necessary in trade.

\section{Developing Countries}

The state of international trade has a great impact on the economy of developing countries most especially for those who basically rely on international trade to increase their GDP. The rapid growth of industrialization together with the formation of numerous multinational corporations has lead to changes in the trade industry. Grossman and Rogoff (2007) explain that "governments set trade taxes simultaneously to maximize their individual objective functions". In this statement the international trade agreement between countries is given attention as it brings advantages and disadvantages.

Moreover, other developing countries on the other hand have a different regime that according to Grossman and Rogoff (2007), "governments set trade taxes jointly to maximize a weighted sum of their objective functions". The international trade agreements may vary among each developing country and modern production techniques have also affected the industry.

Since the industry have risen in half of the 20th century, many countries are now engaging in international trade. It has been established that in engaging in international trade, the country would be able to benefit in terms of GDP, however, another factor is the highly advanced transportation systems wherein developing countries need to cope with others (Shah, 2011).

In their participation to this form of trade, they will have to improve their system individually. Also, the growing transnational corporations may affect the system as it is rapidly evolving together with outsourcing of different products and services as well as a very rapid industrialization (Aswathappa, 2006).

\section{Benefits of International Trade}

The benefits of international trade can be depicted on the countries that have developed their income and those who have obtained trade power over the years. According to Stanley (2011), "nations with strong international trade have become prosperous and have the power to control the world economy. The global trade can become one of the major contributors to the reduction of poverty". This form of trade has flourished over the years due to the fact that countless of benefits can be derived from importing and exporting of goods to other countries most especially in terms of demand and supply and the efficiency of that it offers (Carr \& Indira, 2010).

According to Hata (2008), "a country would consider trading internationally in an effort to give their GDP a big boost very quickly". This is true as some countries have better quality of products and they intend to market it to other countries for exposure and the transaction would be able to generate income (ITA, 2011). This will also be the case in return if a country intends to import goods from other countries that have the products and services they need.

Also, some products can only be found in a certain country such as agricultural products wherein each country has dissimilar weather thus the production of goods may vary in every country. Some agricultural products may be hard to produce in tropical countries while other countries on the other hand have an overflow of supply for that particular agricultural product. Stanley (2011) also listed the following benefits of international trade: 
- Enhances the domestic competitiveness;

- Takes advantage of international trade technology;

- Increase sales and profits;

- Extend sales potential of the existing products;

- Maintain cost competitiveness in your domestic market;

- Enhance potential for expansion of business;

- Gains a global market share;

- Reduce dependence on existing markets;

- Stabilize seasonal market fluctuations.

Among others, engaging in the international trade lead to the exceptional performance of a company to cope up with existing products and service all over the world. Once a country initiates international trade, the import and export of goods is maintained and enhanced to impress other countries or regions for customer satisfaction purposes.

\section{Problems Encountered With International Trade}

Following the boost of industrialization and international trade suddenly the hindrance to the trade industry approached the world. The global crisis has greatly affected the market in the economy became at a loss affecting the whole world. Shah (2010) mentions that, "the extent of this problem has been so severe that some of the world's largest financial institutions have collapsed".

Also, it is at that time when some companies have financial issues that resorted to bankruptcy and eventually closed their businesses. The trade industry went down because the top players in the industry have suffered as well.

Then, the World Trade Organization (WTO) implemented the rules for international trade. According to Anderson and Cavanagh (1997):

The General Agreement on Tariffs and Trade (GATT) was an international organization created in 1947 to reduce trade barriers through multilateral negotiations. In January 1995, the GATT was replaced by a stronger World Trade Organization (WTO), the result of eight years of GATT negotiations. Today, member countries number 125 (nearly the whole world except China, some former communist countries, and a number of small nations) and WTO rules apply to over 90 percent of international trade.

This agreement gave rise to different controversies and misunderstandings because of the wide range of its coverage compared to the GATT agreement that focuses only on the reduction of tariffs among manufactured goods. It has been argued if the Uruguay round would be more effective or the GATT agreement. Most of the businesses all over the world are encountering problems with the rules of these agreements.

Anderson and Cavanagh (1997) explains that the Uruguay round "is slated to result in average tariff reductions of 38 percent for developed economies, reducing average tariffs worldwide from 6.3 percent to 3.9 percent. In comparison, average tariff rates just after World War II were 40 percent. The most controversial outcome of the Uruguay Round was the establishment of much stronger enforcement mechanisms in the WTO". Their policy is deemed to be unfair because it only favors the powerful countries controlling the trade industry while developing countries need to cope up with them. 


\section{Global Exchange Rate}

The powerful players in the trade industry has been expected to depreciate due to the global crisis and recession, but surprisingly in 2008, there is an appreciation in the US dollar occurred rather than depreciation. Then, it has been established that "the adjustment process has taken a very different path with a collapse in asset prices and a massive deleveraging process among financial institutions being at the core of the crisis". Since the United States is one of the powerful players and controls the international trade industry predictions have been made that after the recession in the near 2012 the global exchange rate would depreciate.

This is because that "there was a fairly widespread expectation that a US dollar depreciation would play an important if not central role in the global adjustment process". The decline of US dollar would have a great impact to other countries involved with international trade for the competitiveness and a sustainable investment. Factors that are affecting international trade include pattern of global capital flows from US to elevate cash for redemptions and the foreign investors have changed their equities into a more stable income with countries like the United States. It is shown in Figure 1 that all countries have been affected by the global financial crisis in 2009.

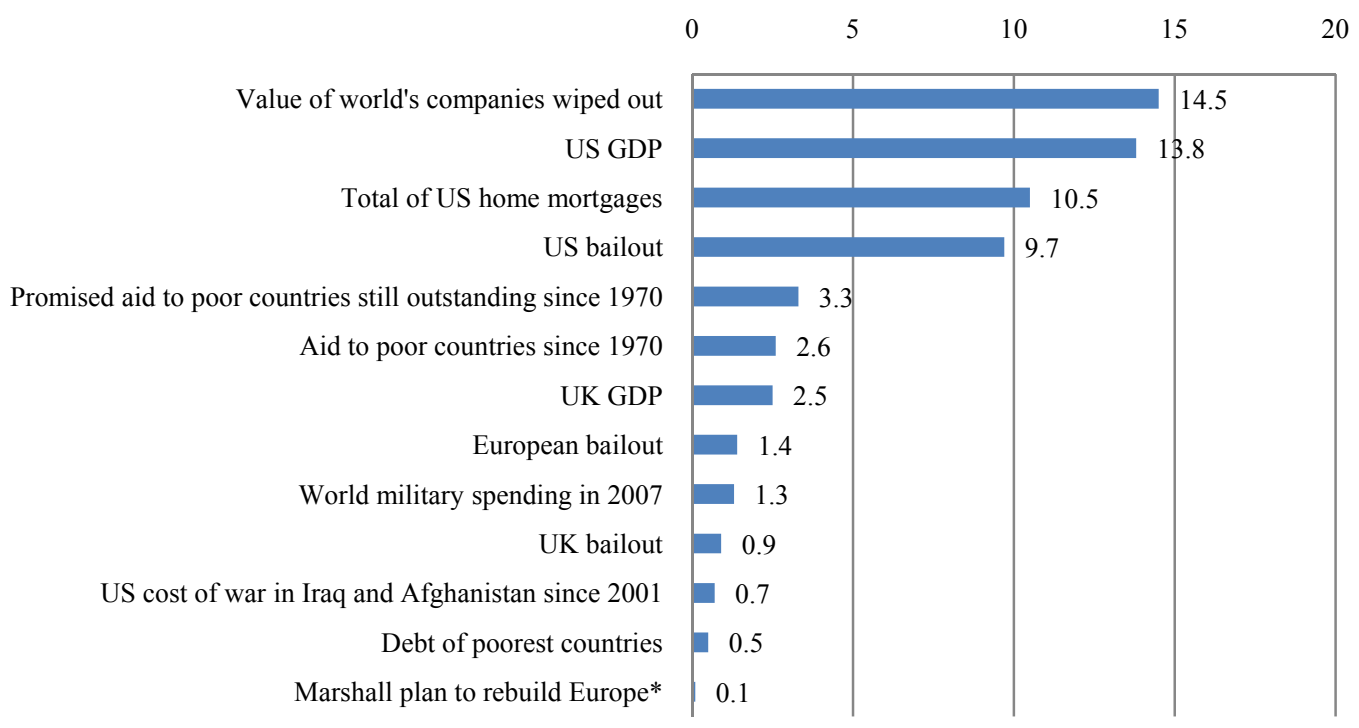

Figure 1. Global financial crisis: Losses and Bailouts for US and European countries in context (in trillion dollars, 2009). ${ }^{*}$ Adjusted for inflation. Source: BBC Bloomberg, UPI, globalissues.org. Feb. 2009.

\section{Law of Supply and Demand}

Also, developing countries believe they get a raw deal when it comes to international trade. They have certain problems which are first of all is "relying on only one or two primary goods as their main exports" (Cohen, 1997). Once the demand or the supply of this goods and services they would have no other option or a contingency source of products. Not only that, they would also need to consider the following factors such as that:

They would not be able to control the price they get for these goods, price they pay for manufactured goods increases all the time, as the value of their exports changes so much long term planning is impossible and the increasing the amount of the primary good they produce would cause the world price to fall. (Feenstra, 2004) 
Another problem arises when it comes to rights. The exchange of goods and services can easily be infringed or copied. A financial website export.gov (2011) suggests that, while trade barriers and unfair practices take many forms, the most common examples are listed below: Intellectual property infringement-including copyright, patent and trademarks; lack of competitive bidding for foreign government tenders; competition from unfairly traded imports; unfair and trade distortive subsidies provided by foreign governments to overseas competitors; foreign trade remedy investigations conducted inconsistent with international obligations; burdensome certification and testing requirements that are not required by domestic manufacturers and increasing imports and unfair competition (Streatfield \& Lacey, 2008).

Together with the advancement in information technology come the problems along with it as well. Weeks (2006) explains that, "the role of communication networks in economic activity has become more and more important". Business firms need to cope with other competing companies with the advancement and development of their communication technologies for international trade transactions. As a consequence of these changes, economic analysis of networks has proven that the relationship between trade and communication networks is highly significant. The barriers arise when the "communications costs which are largely fixed in nature, unlike specific transport costs" (Harrigan, 2004). Since the process of trading internationally deals with making transactions globally the communications cost is higher compared to local networks for international trade uses a worldwide common network services.

\section{Solutions}

The international trade policies are implemented in order to facilitate in a better trading industry. Since the top players in the globe are the ones who are controlling these policies it is only favorable for all countries involved in the international trade industry that fair policies should be implemented. This goes out to the countries that control the industry in terms of tariffs, economic policies, income, copyright policies and infringement, online transactions, advancements in technology, sustainability and the development of countries coping up with the trade industry.

It would only be fair to include the developing countries in making decisions most especially if involves them as well. It has been established earlier that some countries only rely on international trade to increase their GDP therefore it would only be fair to them to implement just policies. Different disagreements and misunderstandings have caused fall outs between existing countries in the industry and this can be minimized if WTO would be able to implement the agreement properly and not to be controlled by US and European countries only.

\section{Conclusion}

Therefore, the international trade paved the way for global transactions and increase in market profitability. With this, numerous benefits have been gained by different countries participating in the trade industry. The advancements in technology have also allowed efficiency and accessibility of information and in doing business transactions.

Benefits include increase in GDP sales and profits, development of quality products and services, market profitability and market size. International trade also extends potential of the existing products, gaining a global 
market share and reduces the dependence on existing markets. These benefits however, have problems along with it.

As mentioned earlier, the international trade industry would be able to minimize certain misunderstandings and disagreements with the proper implementation and fair international trade policies. Moreover, a strict implementation in terms of copyright and infringement policies would also help to solve the different aspects of the country's property rights. The advancements of technology enhances the communication process in doing international business transactions thus different countries participating in the international trade has the need to cope up with the changes in the trade business environment.

The only way international trade would be fair for all is if all the countries had a level playing ground, if all factors were standardized then the potential theoretical benefits of international trade are immense, it would be possible for all countries to benefit and contribute to setting terms of trade, but for now the developed nations are the biggest gainers and the developing nations continue to struggle to reap the benefits of international trade.

\section{References}

Albercht, M., \& Sack, S. (2011, August). International trade statistics 2010. Retrieved from http://www.wto.org/english/res_e/statis_e/its2010_e/its10_toc_e.htm

Anderson, S., \& Cavanagh, J. (1997, January 1). World Trade Organization. Retrieved from http://www.fpif.org/reports/world_trade_organization

Bloomberg. (2009, February). Global financial crisis: Losses and bailout for US and European countries in context. Retrieved from http://www.globalissues.org/issue/1/trade-economy-related-issues

Bloomberg. (2011). Take a closer look at bloomberg. Retrieved from http://www.bloomberg.com/about/

Carr, I. (2010). International trade law. New York: Cavendish Publishing Limited.

Cohen, B. (1997). International trade and finance: New frontiers of research. United Kingdom: Cambridge University Press.

Export.gov. (2011, May 23). Help with trade problems. Retrieved 2011, from http://export.gov/tradeproblems/index.asp

Feenstra, R. C. (2004). Advanced international trade: Theory and evidence. New Jersey: Princeton University Press.

Grossman, G., \& Rogoff, K. (2007). Handbook of international economics. Oxford: Elsevier Publications.

Harrigan, J. (2004). Handbook of international trade (Vol. 1). United Kingdom: Blackwell Publishing Ltd..

Hata, P. (2008, June 18). Benefits of international trade. Retrieved 2011, from http://ezinearticles.com/?Benefits-of-International-Trade\&id=1259699

Heakal, R. (2003, November 25). What is international trade? Retrieved 2011, from http://www.investopedia.com/articles/03/112503.asp\#axzz1VKgk5ftE

International Trade Administration. (2011, June 3). International trade administration office of industry analysis. Retrieved from http://www.trade.gov/mas/ian/index.asp

Larson, B. (1996, May). Information technology and international trade: Resources for the modern exporter. Retrieved 2011, from http://findarticles.com/p/articles/mi_m1052/is_n5_v117/ai_18299930/

Shah, A. (2011, June 5). Trade, economy and related issues. Retrieved 2011, from http://www.globalissues.org/issue/1/trade-economy-related-issues

Streatfeild, J., \& Lacey, S. (2008). New reflections on international trade. USA: Cameron.

Weeks, R. (2006). International trade issues. New York: Nova Science Publishers, Inc..

World Bank.org. (November, 2011). Globalization and international trade (Chapter12, pp. 66-73). Retrieved November 29, 2011, from http://www.worldbank.org/depweb/beyond/beyondco/beg_12.pdf 